\title{
Salt wasting in two neonates with posterior urethral valves: secondary pseudohypoaldosteronism
}

\author{
Posterior üretral valvlı iki yenidoğanda tuz kaybı: sekonder psödohipoaldosteronizm \\ Ülger ALTUNTAŞ, İbrahim GÖKCE, Neslihan Çiçek DENIZ, Meryem BENZER, Halil TUĞTEPE, Serçin GÜVEN, \\ Nurdan YILDIZ, Harika ALPAY
}

\begin{abstract}
Secondary pseudohypoaldosteronism (PHA) is a rare condition that presents with hyperkalemia, hyponatremia, and metabolic acidosis, which develops due to renal tubular unresponsiveness to aldosterone. It may be seen in infants with obstructive uropathy and acute pyelonephritis. Three important reasons of the aldosterone unresponsiveness of the tubules are early infancy kidney, obstructive uropathy, and urinary tract infection. Besides other findings, diagnosis is established with highly increased plasma aldosterone and renin levels. In infants who present with hyperkalemia, hyponatremia, and metabolic acidosis, PHA should be considered in the differential diagnosis of congenital adrenal hyperplasia. Urinary ultrasonography and urine analysis should be performed in these patients. Herein, we present two patients with secondary PHA caused by posterior urethral valves.
\end{abstract}

Keywords: Obstructive uropathy, Secondary pseudohypoaldosteronism, Infant
ÖZ

Sekonder psödohipoaldosteronizm (PHA), böbrek tübüllerinin aldosterona duyarsızlığı ile karakterize, hiperkalemi, hiponatremi ve metabolik asidoz ile kendini gösteren nadir bir durumdur. Obstrüktif üropatisi olan bebeklerde ve piyelonefrit sırasında görülebilir. Gelişimi devam eden erken bebeklik dönemi böbreği, üriner sistemin obstrüktif anomalisi ve enfeksiyonu sekonder PHA hastalarında tübüluslarda aldosteron direncine neden olan üç önemli faktördür. Genellikle hiponatremi, hiperkalemi ve metabolik asidoz ilk bulgulardır, tetkiklerde belirgin olarak yükselmiş plazma renin ve aldosteron seviyelerinin saptanması ile tanı konur. Süt çoçuklarında biyokimyasal incelemede hiperpotasemi, hiponatremi ve metabolik asidoz saptandığında konjenital adrenal hiperplazi ayırıcı tanısında PHA göz önünde bulundurulmalı ve bu hastalarda üriner ultrasonografisi (USG) ve idrar analizi rutin olarak yapılmalıdır. Bu yazımızda sekonder PHA gelişen posterior üretral valv (PUV)'ll iki hasta sunuldu.

Anahtar kelimeler: Obstrüktif üropati, Sekonder psödohipoaldosteronizm, Süt çocuğu

\section{Introduction}

Pseudohypoaldosteronism (PHA) is a clinical condition characterized by hyponatremia, hyperkalemia, and metabolic acidosis, which develops due to unresponsiveness to aldosterone in renal tubular cells. It is classified in two forms as Type 1 (PHA1), and Type 2 (PHA2). Type 1 PHA may result from primary (genetic) or secondary (acquired) causes. In primary PHA1, dysfunction in kidneys and also in other epithelial sodium channel ( $\mathrm{ENaC})$-involving organs (colon, salivary and sweat glands) occurs due to a congenital disorder in $\mathrm{ENaC}$ or mineralocorticoid receptors. PHA2, which is accompanied by hyperkalemia and hypertension, is also called Gordon syndrome or familial 
hyperkalemic hypertension (FHHt), and the disease has an autosomal dominant (AD) transition [1,2]. Renal tubular cells have transient aldosterone resistance in secondary PHA1 and early infant period, urinary tract infections (UTI) and congenital anomalies of the kidney and urinary tract (CAKUT) are the main risk factors for secondary PHA1.

In the present study, we present two patients who underwent valve resection due to posterior urethral valve (PUV) and who developed secondary PHA1. We aimed to emphasize secondary PHA1 in differential diagnosis of hyponatremia and hyperkalemia detected in patients with obstructive uropathy.

\section{Case-reports}

\section{Case-report 1}

Oligohydramnios and bilateral hydronephrosis were detected in the antenatal ultrasonography (USG) of a 10-dayold infant who was delivered through cesarean section in week 35 of pregnancy with a birth weight of $2720 \mathrm{~g}$. The physical development was normal, blood pressure was $80 / 50 \mathrm{~mm} \mathrm{Hg}$, heart rate was $120 / \mathrm{min}$, and genitourinary and other system examinations were normal; however, the infant had difficulty in urinating and interrupted urination. Laboratory examinations revealed the complete blood count and C-reactive protein level (CRP) as normal. Creatinine was $1.9 \mathrm{mg} / \mathrm{dL}$, potassium $7 \mathrm{mEq} / \mathrm{L}$, and sodium 144 $\mathrm{mE} / \mathrm{L}$. Urine analysis and microscopic urine examination were normal. Blood gas analysis was normal. Urinary USG revealed bilateral grade 4 hydroureteronephrosis (HUN), and trabeculation on the bladder wall. A cystoscopy examination revealed PUV, and the infant underwent valve resection on day 10 . Voiding cystourethrography (VCUG) revealed grade 5 vesicoureteral reflux (VUR) in the right ureter. The patient was discharged with antipotassium treatment for hyperkalemia and amoxicillin treatment for UTI prophylaxis. The follow-up sodium level was $128 \mathrm{mEq} / \mathrm{L}$, potassium was $5 \mathrm{mEq} / \mathrm{L}$ under antipotassium treatment, and creatinine was $0.96 \mathrm{mg} / \mathrm{dL}$. Blood gas analysis revealed metabolic acidosis. Polyuria developed during follow-up. Fractional excretion of sodium ( $\mathrm{FeNa}$ ) was high, transtubular potassium gradient (TTKG) was low, and aldosterone and renin levels were detected high. Cortisol, $17 \mathrm{OH}$ progesterone, and adrenocorticotropic hormone $(\mathrm{ACTH})$ were within normal ranges (Table I).
Congenital adrenal hyperplasia (CAH) was excluded with these findings, and the patient was diagnosed as secondary PHA1. Sodium bicarbonate treatment for metabolic acidosis was started.

The patient, who had recurrent UTI during follow-up, required antipotassium and sodium replacement therapy in decreasing amounts. The replacement therapy was stopped at 9 months; the renin level was detected as normal and the aldosterone level was at the upper limit of the normal level. Serum sodium and potassium levels were normal at the last visit when the patient was 3 years of age although the patient did not receive any replacement therapy for 27 months.

\section{Case-report 2}

A 7-day-old boy who was born via a normal vaginal delivery at 36 weeks, with a birth weight of $3040 \mathrm{~g}$ was admitted to pediatric nephrology clinic due to oligohydramnios and bilateral hydronephrosis which were detected antenatally. Physical examination of the baby was normal. Blood pressure was $80 / 50 \mathrm{~mm} \mathrm{Hg}$ and heart rate was $132 /$ min. Genitourinary and other system examinations were normal. The patient underwent valve resection in day 10 after detection of PUV in cystoscopy. The biochemical examinations revealed creatinine as $4 \mathrm{mg} / \mathrm{dL}$, sodium 144 $\mathrm{mEq} / \mathrm{L}$, and potassium $7.2 \mathrm{mEq} / \mathrm{L}$. Blood gas and urine examinations were normal. FeNa was high, TTTK was low, aldosterone and renin levels were detected high (Table I). The patient was initiated antipotassium treatment and developed hyponatremia during follow-up. Cortisol, 17 $\mathrm{OH}$ progesterone, and $\mathrm{ACTH}$ levels were within the normal ranges in accordance with the patient's age (Table I). Congenital adrenal hyperplasia was excluded, and secondary PHA1 due to obstructive uropathy was diagnosed. Sodium replacement therapy was initiated. Valve residue was detected in repeat cystoscopy after the development of a UTI under amoxicillin prophylaxis, and the valve resection was repeated. Voiding cystourethrography revealed bilateral grade 5 VUR. Replacement therapy was stopped at 5 month, and a repeat examination demonstrated that aldosterone and renin levels were declining. Renin and aldosterone levels were detected as normal at the last visit when the patient was 2.5 years of age. Serum sodium and potassium levels were within the normal ranges although the patient did not receive replacement therapy for 25 months. 
Table I: Biochemical and hormonal characteristics of the patients

\begin{tabular}{|l|c|c|c|}
\hline & Case 1 & Case 2 & Reference ranges \\
\hline Sodium $(\mathrm{mEq} / \mathrm{L})$ & 128 & 135 & $135-145$ \\
\hline Potassium $(\mathrm{mEq} / \mathrm{L})$ & $5^{*}$ & 7.2 & $3.5-4.5$ \\
\hline Bicarbonate $(\mathrm{mmol} / \mathrm{L})$ & 19 & 21 & $22-26$ \\
\hline Plasma renin activity $(\mathrm{ng} / \mathrm{L})$ & 117 & 270 & $3-16$ \\
\hline Plasma aldosterone activity $(\mathrm{pg} / \mathrm{mL})$ & 1285 & 3300 & $29.4-161.5$ \\
\hline $17 \mathrm{OH}$ progesterone $(\mathrm{ng} / \mathrm{mL})$ & 1.47 & 8.1 & $0.7-5$ \\
\hline ACTH $(\mathrm{pg} / \mathrm{mL})$ & 45.4 & 14.8 & $0-46$ \\
\hline Cortisol $(\mu \mathrm{g} / \mathrm{dL})$ & 17.04 & 14.5 & $6.2-19.4$ \\
\hline FeNa $(\%)$ & 3 & 9.7 & $<1$ \\
\hline TTKG $(\%)$ & 3 & 4.8 & $>8$ \\
\hline Urinary anomaly & PUV + VUR & PUV + VUR & \\
\hline Urinary tract infection & Yes & Yes & \\
\hline
\end{tabular}

* During antipotassium treatment, FeNa: Fractional excretion of sodium, TTKG: Transtubular potassium gradient, PUV: Posterior urethral valve, VUR: Vesicoureteral reflux

\section{Discussion}

Posterior urethral valve is the most frequent congenital anomaly that causes obstructive uropathy in males. The disorder develops in the early gestational period and causes significant bladder dysfunction and kidney damage due to high pressure exposure of the bladder and upper urinary system. Obstruction causes glomerular and tubular dysfunction, and concentration and acidification ability of the tubules are damaged, therefore polyuria, sodium wasting in urine and electrolite imbalance develop [3,4]. Asano et al., reported that the increased intrarenal pressure in obstructive uropathy increases cytokine synthesis and causes tubular dysfunction. In addition, the obstruction decreases kidney blood flow, and this activates the renin-angiotensin system and increases aldosterone levels [5].

Pseudohypoaldosteronism is a clinical condition characterized by salt wasting and hyperkalemia due to aldosterone resistance in tissues. Early infancy period, CAKUT and UTI are three significant factors that cause aldosterone resistance in tubules of patients with secondary PHA1. Secondary PHA1 may also be classified as Type 3 PHA (PHA3) and is known as transient PHA1. Various anomalies of the urinary system (ureterohydronephrosis, ureterocele, ureteropelvic obstruction) may cause secondary PHA1. Bogdanović et al., investigated 85 patients with secondary PHA1 and reported that $90 \%$ of total 93 patients with secondary PHA1 were aged younger than three months of age. Urinary sytem anomalies accompanied in $90 \%$, and UTI was present in approximately $89 \%$ of patients. In addition, they reported that the rate of PUV was $19 \%$ in these anomalies [6]. Both patients in our study were aged younger than 3 months, they had obstructive uropathies secondary to PUV, and UTI accompanied during follow-ups.

Although many diseases cause hyponatremia, hyperkalemia, and metabolic acidosis during infancy, exclusion of $\mathrm{CAH}$ is important in these patients. Masculinization in girls, and rapid penis growth in boys may be observed in the salt wasting form of $\mathrm{CAH}$. Vomiting and dehydratation are detected in both sexes a short while after birth. The differential diagnosis of PHA and CAH may sometimes be difficult. The literature indicates that these patients may frequently be misdiagnosed. Pai et al., initiated hydrocortisone and fludrocortisone in 3 infants with $\mathrm{CAH}$ who were hyponatremic, hyperkalemic, and with symptoms of vomiting and severe dehydration. However, the patients were diagnosed as PHA when laboratory examinations were done, and urinary system anomalies (ureteropelvic obstruction, megaureter, double system), and UTI were detected [7]. Authors have indicated that adrenal steroids were frequently given to the patients with secondary PHA1 with the initial diagnosis as $\mathrm{CAH}[7,8]$.

Contrary to that, Ağladıoğlu et al., first diagnosed their patients as having PHA, and they were then diagnosed as $\mathrm{CAH}$ after ACTH stimulation test and genetic analysis; renin aldosterone and basal ACTH levels were found to be elevated in two patients in their report [9]. The genital 
examinations of our patients were normal. We thought that high levels of potassium during the first presentation developed secondary to kidney dysfunction. The patients had hyponatremia, metabolic acidosis, and salt wasting from urine during follow-up and were diagnosed as having secondary PHA1 after the detection of high levels of renin and aldosterone levels. Other adrenal hormones and ACTH levels were within the normal ranges in both patients. Repeat examinations showed that renin and aldosterone levels were declining, and no increase was detected in ACTH levels. We did not suspect $\mathrm{CAH}$ owing to the clinical and laboratory data. We did not require a genetic investigation or $\mathrm{ACTH}$ stimulation test.

Salt wasting and growth retardation are generally detected in the neonatal period of patients with primary (genetic) PHA1, and the disease has two types. Generalized or autosomal recessive (AR) PHA1 develops due to a mutation and function loss of $\mathrm{EnaC}$, which is present in most organs. The clinical condition is more severe in these patients due to salt wasting from the kidneys, colon, salivary and sweat glands. However, clinical symptoms are mild, and limited to the kidneys in renal or AD PHA1, which stems from the NR3C2 gene mutation, which encodes the mineralocorticoid receptors. Clinical symptoms become milder with age in these patients. Salt replacement is generally not required after 2 years of age owing to the increase of sodium reabsorption maturation in renal tubules with advanced age. Clinical and laboratory findings of secondary PHA1 are similar to the findings those are present in AD PHA1. Urinary USG and history of UTI are important in the differentiation of secondary PHA1 from primary PHA1. Bowden et al., diagnosed their patients as having AD PHA1 after detection of NRC2 gene mutation, which they conducted because although the clinical condition improved, a high level of aldosterone was maintained in their patients who they first diagnosed as having secondary PHA1. The same gene mutation was detected in the patient's mother; however, she was asymptomatic, and hormonal examination revealed high level of aldosterone. The author emphasized that NR3C2 DNA analysis must be performed for patients who maintain high serum level of aldosterone after treatment of urinary system anomalies or UTI, and patients who present with clinical symptoms of secondary PHA1 must be suspected of having primary AD PHA1 [10]. In another similar case, an infant with acute pyelonephritis was first diagnosed as having secondary PHA1. In this baby due to continued high renin and aldosterone levels after clinical recovery, the patient's asymptomatic mother and two siblings were investigated and high levels of renin and aldosterone were detected. In this case, where genetic examination could not be performed, the authors reported that although AD PHA1 could be detected as asymptomatic in the clinic, the findings of disease could be clinically detected with accompanying secondary factors such as inflammation, which cause transient tubular dysfunction [11]. Replacement therapy was interrupted in month 9 in our first case; the renin level was normal and aldosterone level was at the upper limit of the normal values in repeat hormonal examinations. Replacement therapy was interrupted in month 5 in our second case, and high levels of renin and aldosterone were maintained in decreasing levels. However, renin and aldosteron levels were found normal in a repeat examination at 2.5 years of age. None of our patients required replacement therapy during their pediatric nephrology follow-up, which lasted more than 2 years. We did not perform a family investigation because primary PHA1 was excluded with clinical and laboratory findings.

In conclusion, secondary PHA1 is a rare clinical condition that develops in early infancy. Pediatricians must suspect PHA in addition to $\mathrm{CAH}$ in infants with salt wasting and hyperkalemia, and must perform urinary USG and simple urine analysis. Furthermore, serum electrolytes of infants who have urinary tract anomalies or infections must be closely monitored.

\section{References}

1. Devuyst O, Konrad M, Jeunemaitre X, Zennaro MC. Tubular disorders of electrolyte regulation. In: Avner ED, Harmon WE, Niaudet P, Yoshikawa N, editors. Pediatric Nephrology. 6th ed. Berlin Heidelberg: Springer-Verlag, 2009; 929-77.

2. Goodyer P. Disorders of tubular transport. In: Kher KK, Schnaper HW, Makker SP, editors. Clinical Pediatric Nephrology. 2nd ed. London: Informa Healthcare, 2006; 317-36.

3. Nasir AA, Ameh EA, Abdur-Rahman LO, Adeniran JO, Abrahan MK. Posterior urethral valve. World J Pediatr 2011;7:205-16. doi: 10.1007/s12519-011-0289-1

4. Hodges SJ, Patel B, McLorie G, Atala A. Posterior urethral valves. ScientificWorldJournal 2009; 9:1119-26. doi: 10.1100/tsw.2009.127

5. Asano T, Abe M, Asai M, et al. Urinary tract malformation and infection with hyperkalemia and decreased fractional excretion of potassium in an infant. J Nippon Med Sch 2006;73:289-91. doi: http://doi.org/10.1272/jnms.73.289

6. Bogdanović R, Stajić N, Putnik J, Paripović A. Transient type 1 pseudo- hypoaldosteronism: report on an eight-patient series and literature review. Pediatr Nephrol 2009;24:216775. doi: 10.1007/s00467-009-1285-8 
7. Pai B, Shaw N, Högler W. Salt - losing crisis in infants - not always of adrenal origin. Eur J Pediatr 2012;171:317-21. doi: 10.1007/s00431-011-1541-3

8. Nandagopal R, Vaidyanathan P, Kaplowitz P. Transient pseudohypoaldosteronism due to urinary tract infection in infancy: A report of 4 cases. Int $\mathrm{J}$ Pediatr Endocrinol 2009;2009:195728. doi: 10.1155/2009/195728

9. Ağladıoğlu SY, Aycan Z, Kendirci HN, Erkek N, Baş VN. Does pseudohypoaldosteronism mask the diagnosis of congenital adrenal hyperplasia? J Clin Res Pediatr Endocrinol 2011; 3:219-21. doi:10.4274/jcrpe.369
10. Bowden SA, Cozzi C, Hickey SE, Thrush DL, Astbury C, Nuthakki S. Autosomal dominant pseudohypoaldosteronism type 1 in an infant with salt wasting crisis associated with urinary tract infection and obstructive uropathy. Case Rep Endocrinol 2013;2013:524647. doi:http://dx.doi. org/10.1155/2013/524647

11. Bayer M, Kutílek S. A hereditary form of pseudohypoaldosteronism may be manifested in the course of pyelonephritis. Acta Paediatr 1993; 82:504. doi: 10.1111/ j.1651-2227.1993.tb12736.x 